\title{
"From jelly babies to Roman candles", Science et culture dans Science in Action (BBC World Service)
}

\section{Pierre Vuillaume}

\section{CpenEdition}

\section{Journals}

Édition électronique

URL : http://journals.openedition.org/asp/4102

DOI : 10.4000/asp.4102

ISSN : 2108-6354

\section{Éditeur}

Groupe d'étude et de recherche en anglais de spécialité

\section{Édition imprimée}

Date de publication : 1 décembre 1994

Pagination : 231-236

ISSN : 1246-8185

\section{Référence électronique}

Pierre Vuillaume, " "From jelly babies to Roman candles", Science et culture dans Science in Action

(BBC World Service) », ASp [En ligne], 5-6 | 1994, mis en ligne le 19 décembre 2013, consulté le 21 avril 2019. URL : http://journals.openedition.org/asp/4102 ; DOI : 10.4000/asp.4102

Ce document a été généré automatiquement le 21 avril 2019

Tous droits réservés 


\title{
"From jelly babies to Roman candles", Science et culture dans Science in Action (BBC World Service)
}

\author{
Pierre Vuillaume
}

1 L'émission radiophonique de vulgarisation scientifique Science in Action a servi de base à un travail de didactisation de documents authentiques que j'ai effectué au cours de l'année 1992-93 avec des élèves-ingénieurs de l'Institut Universitaire des Sciences Pour l'Ingénieur (IUSPIM) de l'Université Aix-Marseille 3, dans le but d'améliorer leur compréhension orale. Par ailleurs, le Professeur Claude Roman, Directeur du Département de Neuro-Sciences de la Faculté des Sciences de Saint-Jérôme, à Marseille, Doyen de cette Faculté, et spécialiste de gastro-entérologie, préparait un congrès, pour l'été 1993. Il désirait établir avec l'anglais oral un contact plus suivi et plus intense. Je lui ai alors régulièrement communiqué les documents de travail que je préparais pour mes élèves-ingénieurs ainsi que les enregistrements complets des émissions d'où ils étaient tirés.

2 En fin d'année, j'ai demandé aux élèves de répondre à un questionnaire sur Science in Action et sur le travail que nous avions effectué. Le Doyen Roman a souhaité y répondre également. L'un des commentaires que j'ai trouvés sous sa plume a été: "C'est une excellente façon de se cultiver tout en se mettant dans l'oreille de l'anglais. »

3 Le thème du XV colloque du GERAS, «Langue de spécialité et culture " m'ayant amené à réfléchir sur l'émission en tant qu'instrument de culture, il m'a semblé que l'avis d'un collègue scientifique ayant eu un contact régulier avec Science in Action était précieux. Le commentaire que je viens de citer m'a tout naturellement conduit à interroger le Doyen Roman, et nous nous sommes entretenus de ce sujet, en partant d'un extrait représentatif, à mes yeux, des différentes façons dont la notion de culture pouvait être associée à l'émission. Il s'agit d'un extrait qui date du 7 mai 1993, et sur lequel j'ai travaillé cette année avec, cette fois, des étudiants de Maîtrise, spécialistes de chimie et de géologie. 
4 Je me propose de présenter cet extrait en en soulignant les caractéristiques. Je citerai ensuite certaines observations du Doyen Roman, puis je ferai rapidement allusion à d'autres extraits sur lesquels j'ai eu l'occasion de travailler, et à ma rencontre avec une partie de l'équipe de Science in Action. Cette rencontre inspirera ma conclusion.

5 Voici cet extrait, qui porte sur la poudre à canon. Ce sont des notions de culture générale qui servent d'introduction, associant ainsi un produit chimique à son histoire :

Andrew Dunn: Gunpowder has a fascinating history. It's made from charcoal, saltpeter and sulphur; and it was discovered by the Chinese over a thousand years ago. It came to England in about 1250, when the monk who worked out the formula wrote it down in Latin and sent it to the Pope, asking him never to let it out, because gunpowder was too dangerous for the common people.

On établit ensuite un lien entre l'histoire, la science, et le monde contemporain. Au moment d'exploiter ce texte en cours, une référence à Guy Fawkes s'imposera. Mais revenons à un élément essentiel de la démarche scientifique, donc de la culture scientifique : on met en évidence un problème, et une solution va être proposée, ici par l'auteur des recherches lui-même.

Well, one of its main uses today is in fireworks. But problems with gunpowder production have led Professor Alan Baley, and his fellow chemists at the Royal Military College of Science in Wiltshire, to develop a safer and cheaper polymerbased alternative.

He explained to Chris Westcott that one problem with making gunpowder is the shortage of older trees, which make the best charcoal; and the other is that sulphur is downright dangerous: 2,000 people died worldwide in firework factories last year alone.

7 La solution proposée est alors expliquée plus précisément. Les termes deviennent plus scientifiques, susceptibles d'intéresser le spécialiste, mais restent toutefois accessibles au profane. Un des principaux soucis des réalisateurs de cette émission est de ne pas oublier qu'ils s'adressent à ces deux types d'auditeurs.

A.B.: When sulphur comes in contact with sodium chlorate, which is one of the commonest ingredients of fireworks, then, a very dangerous mixture is prepared, and it's very, very sensitive, if not even spontaneously inflammable. So, in a firework factory sulphur and chlorate have got to be kept scrupulously separate. And if sulphur can be eliminated from the mixtures, then it makes life in a firework factory much easier.

C.W.: So it's the sulphur that's the problem. You've been working on a new type of gunpowder, presumably that doesn't contain sulphur.

A. B.: Yes, that's right. We have developed a replacement for gunpowder which doesn't contain sulphur.

8 On n'en saura pas plus sur ce produit de substitution. Nous nous interrogerons par la suite, avec les étudiants, sur les raisons de cette discrétion et mettrons ainsi en évidence un nouvel élément lié à la culture : ce choix délibéré est en rapport avec le moyen d'expression choisi.

9 En effet, le même sujet a été traité dans New Scientist du 6 novembre 1993, et l'étude parallèle des deux documents, au moyen d'une grille de comparaison, a permis aux étudiants de remarquer, entre autres, que l'aspect purement scientifique était plus développé dans la revue scientifique. D'autres éléments ont été étudiés dans cette optique, ce qui nous a donc conduits à parler de façon plus générale des contraintes de la presse écrite et de celles de l'information radiodiffusée. 
10 Dans l'immédiat, revenons sur l'aspect technologique, aspect essentiel puisque lié à des problèmes de sécurité dans le travail :

But, the other advantage is that it can be made by completely different methods. Gunpowder is made in gunpowder mills, and many of the mills in history blew up with catastrophic circumstances. So, to get away from that kind of manufacture would also be a big advantage, just as much an advantage as leaving out the sulphur.

11 Nous arrivons maintenant au passage qui a donné son titre à cette communication. Y apparaissent différents aspects culturels : un contexte sociologique et familial que le Professeur Baley va nous livrer (et que son accent nous avait permis de situer dans le Lancashire) ; le rôle du hasard dans certaines découvertes, dont les exemples jalonnent l'histoire des sciences ; des mots tels que «jelly babies", à forte charge affective, pour le Professeur Baley mais aussi pour tout jeune Britannique ; et aussi une langue propre aux procédés technologiques.

C. W.: Now, I understand that you've paid attention not just to gunpowder but also to the stars that are going to fireworks such as Roman candles, and your idea for this, I'm led to believe, came from your knowledge of how confectionery is made, in particular jelly babies. Now, go on, tell me, what's the link between jelly babies and Roman candles?

A. B.: My father, my father is the link. When we make these new materials for the firework industry, they are based on a plastic material which starts life as a very sticky liquid. (It) looks a little bit like dark trickle. And because it's so sticky, it will stick to absolutely anything.

And my father used to work in the liquorice allsorts factory in Pontefract. And one of the things that they used to make was jelly babies. And I've often seen them as a small child being made. And they're made by putting starch into a tray. And then the moulds press the shape of the jelly baby into the dry starch, and a little blob of jelly is placed into each indentation, and it takes up the shape of the jelly baby in the starch and when the jelly has set you tip the whole lot out into a sieve and the starch falls through and the jelly babies are left behind.

And it struck me that this was the perfect technique for casting these sticky materials to make the stars for Roman candles and sky rockets and... and so on.

So, we, in fact, used the same kind of technique, using a white powder and pressing the shape and putting the blob into the depression to set.

12 Aspect culturel inattendu, le mot «blob» sera l'occasion pour les étudiants d'élargir la culture de leur professeur en évoquant un film dont Steve McQueen était l'acteur principal et qui porte ce titre, et dont une nouvelle version a été tournée. C'est aussi aux étudiants que l'on devra de ne pas traduire « sieve » par « tamis », mais par « claie ».

Retour, cependant, aux débouchés actuels de la poudre à canon, et, du même coup, au monde contemporain :

C. W.: So clearly there are a number of advantages for the manufacture of fireworks, but fireworks themselves are, presumably, to be classified as no more than, if you like, a social use of gunpowder. You, however, work in a military college of science. Are there any potential military, or industrial uses for these new types of gunpowders and these new manufacturing techniques?

A. B.: There are. The military requirement these days has moved on long beyond gunpowder and they're looking for very, very high performance materials. But, on the commercial side, in things like signalling rockets, maroon, flares, distress rockets, those applications will find an outlet for this material; and also, the quarrying of slate is still done using gunpowder. And this material will be applicable in that sort of... application, where only a gentle explosion is required 
and gunpowder by comparison with things like $\mathrm{T} \mathrm{N} \mathrm{T}$ and Semtex and what have you, is a very gentle explosion.

(hat was Professor Alan Baley, an eclectic scientist if ever there was one. I think I'd like to see a very gentle explosion. Maybe we should now fade out with a bang... Till next week, from my producer, Chris Westcott and from me, Andrew Dunn, good-bye.

Laissons-les donc « s'esquiver avec fracas », mais non sans avoir signalé au passage qu'au cours des trois minutes cinquante secondes qu'a duré l'entretien nous aurons rencontré, outre deux oxymorons ${ }^{1}$, une trentaine de mots appartenant au vocabulaire à orientation générale scientifique et technique, et une trentaine de mots scientifiques plus spécialisés.

L'exemple que j'ai choisi m'a paru significatif et, contrairement à ce que déplore Clive Cavendish Rassam (1993), des scientifiques sont très régulièrement invités par les réalisateurs de Science in Action pour nous faire ainsi découvrir de nombreux aspects de la culture scientifique.

Il n'en devenait que plus intéressant d'avoir l'avis d'un scientifique français sur la valeur d'une émission dont il était devenu un auditeur familier : selon le Doyen Roman, il s'agit d'une émission bien faite, et de grande valeur. Il se trouve qu'il s'est lui aussi intéressé au reportage sur la poudre à canon :

J'ai appris, d'ailleurs, à ce propos, comment on faisait de la poudre à canon, à partir de quels matériaux, pourquoi elle était instable, et comment on pouvait la stabiliser. J'ignorais tout... Je ne suis pas spécialiste des poudres. Ça paraît finalement relativement simple, et on comprend qu'il ait pu y avoir des accidents, parce qu'il y a des composés qui, effectivement, mis en présence, sont spontanément explosifs. Là j'ai appris des choses qui sont totalement en dehors de ma spécialité. Ça m’a intéressé.

Je l'avais sur bande, non traduit, ce qui fait que j'ai dû l'écouter plusieurs fois et, de temps à autre, chercher quelques mots sur le dictionnaire.

L'existence des "jelly babies» aussi a été une découverte. Plus généralement, notre collègue scientifique a appris, en écoutant l'émission régulièrement, un certain nombre de choses dans des domaines qui ne sont pas le sien, présentées de façon intéressante.

Et la culture? Je reviens sur son expression " une excellente façon de se cultiver », plus habituellement associée, il faut bien l'avouer, aux arts, à la littérature...

21 Je ne suis pas d'accord. Je crois que la science est en plein dans la culture, et que c'est la culture elle-même. Lorsque, dans cette émission, on entend parler de thérapie génique, de la correction éventuelle des effets nocifs de certains gènes qui permettrait de corriger, voire de modifier tel ou tel état pathologique et, pourquoi pas, dans quelques décennies, voire dans quelques siècles, de corriger également certains défauts de la pensée, on arrive en plein dans un domaine de culture qui pose des problèmes quasiment métaphysiques. Et je pense que ça touche, en plein, à des problèmes de culture. Tout citoyen honnête doit savoir ces choses-là.

22 Notre entretien se terminera sur l'évocation des différentes personnalités et les différents accents des invités de l'émission, autres éléments associés à la culture, qui nous 
amèneront à conclure sur l'anglais, « support véhiculaire indispensable, en science, pour communiquer », selon le Doyen Roman.

Les élèves-ingénieurs qui ont fait l'objet de ma note de recherche de DEA en 92-93 sont spécialistes en informatique et en robotique, et j'avais sélectionné pour eux des extraits traitant essentiellement de ces sujets. Sachant que, cette année, j'allais avoir des spécialistes en chimie, j'ai décidé d'exploiter l'entretien que nous venons d'écouter. L'émission est en fait une source de documents variés, que l'on peut décider d'utiliser en fonction du public choisi.

C'est pourquoi j'étais tenté, en préparant cette communication, de présenter pour finir une sorte de palette des différents sujets traités. Je me contenterai de dire que les différents domaines de la science y sont abordés en fonction de l'actualité, et que j'aurais pu faire une analyse du même type que celle que je viens de faire avec bon nombre d'extraits portant sur l'informatique, la médecine, l'astronomie, la paléontologie, ou... les rapports entre la science et la culture. Or j'ai eu la possibilité d'aller sur place rencontrer une des équipes de l'émission un vendredi, jour de sa diffusion en direct. Je voudrais donc, pour finir, citer un extrait de l'entretien que Chris Westcott, un des réalisateurs de l'émission, m'a accordé, et dans lequel il était question d'une de ses préoccupations, qui est aussi la nôtre, la langue utilisée :

I think the language in which we recount the story is very important. Indeed, it's probably the most important thing that we do. Because, with radio, it is only the words that the listener hears. With television you can rely on pictures as well to convey the story. If you're reading something in a scientific journal or a magazine, if you don't quite understand something you can go back over and read the paragraph again. The thing about radio is once those words have gone past your ears, they are gone for ever. And so, you have to be very careful about how the story is constructed so that people can follow the story.

And so what we always try and do is to make the story understandable to everybody. The important point about Science in Action as a program is that it is a science news and current affairs program, and should be as accessible to everybody as any other kind of news and current affairs program would be. The only difference is that Science in Action deals with the scientific stories of news and current affairs. Whereas other current affairs programs deal with politics, and economics, and social issues.

So we would use the same criteria for selecting interviews and the way in which we conduct interviews as any other current affairs producer would use.

Having said that, it is sometimes, in fact, quite often the case, very difficult to turn what may be very arcane language, very complicated constructs, indeed, very complicated concepts that you find in many scientific publications into something that everybody can understand. And that is the challenge, and also the thrill in the job ; because, if you do that well you succeed, if you do it badly, then, you fail.

Les personnes qui m'ont accueilli à la $\mathrm{BBC}$ se sont, pour leur part, intéressées à mon travail. Je conclurai mon propos par les explications qui, ce jour-là, m'ont servi d'entrée en matière: Science in Action a sans aucun doute une dimension culturelle et le professeur d'anglais trouve là une source de motivation pour ses étudiants et l'occasion d'une ouverture sur notre monde : les sujets sont intéressants, variés, en rapport direct avec l'actualité scientifique ; ils sont traités avec rigueur et talent, dans une langue que le nonspécialiste peut aborder, car elle est le reflet d'un effort que le spécialiste fait dans sa direction. Et le spécialiste - nous avons eu le témoignage du Doyen Roman - y trouve aussi « une excellente façon de se cultiver ». 


\section{BIBLIOGRAPHIE}

Rassam, Clive Cavendish. 1993. The Second Culture, British Science in Crisis, The Scientists Speak Out. Londres: Aurum Press.

\section{NOTES}

1. Oxymoron : figure de rhétorique qui consiste à allier deux mots de sens incompatibles pour leur donner plus de forme expressive. Assez étrangement, le Larousse encyclopédique donne comme traduction des mots qui sont à l'origine de "oxymoron " oksus, piquant, et moros, émoussé, alors que le Dictionnaire Robert donne oxus, aigu, fin, et moros, sot, fou.

\section{RÉSUMÉS}

L'exploitation de Science in Action dans différents cours d'anglais destinés à des élèves-ingénieurs au cours de l'année universitaire 1992-93 a donné lieu à une série d'échanges, non seulement avec les étudiants, mais encore avec un collègue scientifique, spécialiste de neuro-sciences. À l'occasion d'un bilan sur le travail fait avec ce support, ce collègue a parlé, à propos de l'émission, d'une "excellente façon de se cultiver». Il a accepté de préciser sa pensée au cours d'un entretien. Science in Action est donc analysé à la lumière de ses observations. C'est l'occasion de mettre en évidence les différentes façons dont la notion de culture s'y trouve associée: des références à l'histoire, à la démarche scientifique, à la vie quotidienne et à la civilisation illustrent cette association. La langue utilisée fait l'objet d'observations, en particulier à partir de l'extrait d'un entretien accordé par Chris Westcott, un des réalisateurs de l'émission.

Science in Action (BBC World Service) was used as teaching material for a course given to student engineers in 1992-93. In June 1993, the students were asked to assess the work which had been done and the material. So was a colleague, a specialist in neuro-sciences, who had taken part in the experiment. He wrote that the program "was an excellent source of culture". He agreed to give an interview and develop the statement. Science in Action is therefore analysed in the light of his observations. The program's association with culture is stressed through references to history, to the scientific approach, to every-day life and to civilisation. References to the language used in the program are based on excerpts from an interview with Chris Westcott, a producer of the program.

\section{INDEX}

Mots-clés : BBC, culture, radio, science

Keywords : $\mathrm{BBC}$, culture, radio, science 


\section{AUTEUR}

\section{PIERRE VUILLAUME}

Pierre Vuillaume enseigne à la Faculté des Sciences de l'Université d'Aix-Marseille 3. pierre.vuillaume@sfr.fr 